\title{
STUDIES ON MACRO-ZOOBENTHOS IN ASHTI LAKE, DISTRICT WARDHA
}

\section{(M.S.) INDIA}

\author{
U. W. Fule ${ }^{1}$, S. S. Nimgare ${ }^{1}$, P. M. Telkhade ${ }^{2}$ and S. B. Zade ${ }^{3}$ \\ 1 Hutatma Rashtriya Arts and Science College, Ashti, District Wardha, M.S., \\ India. \\ 2 Arts, Commerce and Science College, Tukum, Chandrapur, MS, India. \\ 3 P.G.T.D Dept of Zoology R.T.M.Nagpur University, Nagpur, MS, \\ India. Corresponding author Email : ptelkhade@yahoo.in
}

\begin{abstract}
:
Invertebrate communities respond to changes in water and habitat quality and integrate impacts over a time period because of their extended residency period in specific habitats and presence or absence of specific species can be indicative of specific environmental and habitat conditions. The diversity and seasonal variation in macro-zoobenthic fauna of Ashti lake, Ashti, Dist-Wardha have been studied on the basis of collection obtained from monthly surveys for a period of 1 year (December 2012 to November 2013). The macro-zoobenthic fauna belonged to Nematoda represented by two species Viz. Diplogaster factor and Rhabdolimus minor. Two species of Annelida were Pristima aequiseta and Tubifex tubifex. Arthropoda represented by four species and they were Notonecta glauca, Diptera larva, Chironomus larva and mosquito larva. Mollusca was the most dominant group represented by eight species viz. Bellamya bengalenis, Indoplanorbius exustus, Thiara tuberculata, Thiara scabra, Lymnaea accuminata, Faunus ater, Pila globosa and Ligumia lattisima.
\end{abstract}

\section{Keywords:}

Macro-zoobenthos, Ashti lake, Seasonal variation.

\section{Introduction:}

The abundance of benthic fauna greatly depends on physical and chemical properties of the substratum. Benthic macro-invertebrates can be used as a barometer of overall biodiversity in aquatic ecosystems. Invertebrate communities respond to changes in water and habitat quality and integrate impacts over a time period because of their extended residency period in specific habitats and presence or absence of specific species can be indicative of specific environmental and habitat conditions. Invertebrates are abundant and diverse in most of the aquatic habitats and are relatively easy to sample 
and analyze. They are relatively immobile and cannot avoid â $€^{\sim} E^{2}$ entsâ€ $€^{\mathrm{TM}}$ or â€ Pulsesâ $€^{\mathrm{TM}}$ of pollutants or other forms of stress often missed by conventional water or habitat quality sampling (Vikram Reddy and Malla Rao, 1997). In India studies on macro-benthos had earlier been carried out by Michael (1968), Mandal and Moitra (1975),Vasisht and Bandal (1979), Sarkar (1989), Reddy(1991), Chandrasekhar(1997) and Archana (2003). The aim of present study is to evaluate seasonal variation of macro-zoobenthos in Ashti lake, Ashti, Distrct Wardha.

\section{Material and Method:}

In order to cover all the topography of the lake, four sampling sites viz. Site-I (South), Site-II (North), Site- III (East) and Site- IV (West) were selected . During the period of investigation (December 2012 to November 2013) monthly samples were collected for qualitative and quantitative estimation of benthic fauna. A core sampler of $4.5 \mathrm{~cm}$. in diameter and $12.0 \mathrm{~cm}$. in length was used for scooping the sediment to a depth of $10 \mathrm{~cm}$., each sample being apart from the other by a distance of 2 meters at each site. The mud samples were transferred to the laboratory in polythene bag for further analysis. The collected mud was transferred to a measuring cylinder and volume was measured. To sort out the organisms in each sample, a suspension prepared in water was filtered through $2 \mathrm{~mm}$ and $0.5 \mathrm{~mm}$ mesh size. The filtered residue was transferred in to a tray and sugar solution (10 gm. / $250 \mathrm{ml}$ water) was poured on it. Due to increase in the density of water benthic organisms will float on the surface and can be easily picked up with the help of dropper. All the collections were preserved in $5 \%$ formalin for identification up to species, species composition, population density, spatial distribution and temporal variation. With the help of scoop and direct collection the macro-zoobenthic organisms were collected in labeled bottles. The counting was done with the help of Sedgewick Rafter cell under binocular research microscope. 


\section{Result And Discussion:}

The macro-zoobenthic fauna from Ashti lake, belonged to four major groups of which Nematoda and Annelida represented by two species each; Arthropoda represented by four species and Mollusca represented by eight species. Nematoda Two species of Nematoda were observed viz. Diplogaster factor and Rhabdolimus minor. D. factor was found at all the sites in all the seasons but was absent in monsoon at Site-I and in summer at Site- II and III.R. minor was observed only in winter at Site- I and III while in monsoon and winter at Site-II and IV. Annelida Two species of Annelida were observed viz. Pristima aequiseta and Tubifex tubifex. P. aequiseta was present in all the seasons at Site- III while in monsoon and winter at site-II and IV and in winter and summer at Site-I. Arthropoda Notonecta glauca, Diptera larva, Chironomus larva and mosquito larva were the four observed species of Arthropods. N.glauca was observed at Site-I and III in monsoon, at Site-II and IV in monsoonand winter. Diptera larvae were found in winter and summer at Site-I, II and IV while in monsoon and winter at Site-III. Chironomus larva was observed in all the seasons at Site-II while in monsoon at Site-I and III and in monsoon and winter at Site-IV. Mosquito larvae were found only in monsoon at Site-I while in monsoon and winter at Site-II and IV and in winter and summer at Site-III.

Mollusca Mollusca was the most dominant group represented by eight species viz. Bellamya bengalenis, Indoplanorbius exustus, Thiara tuberculata, Thiara scabra,Lymnaea accuminata, Faunus ater, Pila globosa and Ligumia lattisima. Their seasonal variation at Site-I and II is given in Table- 1and at Site-III and IV is shown in Table-1. Many studies have established that the organic enrichment of the bottom supports a qualitative increase of Oligochaeta and a reduction in chironomidae (Mylinski and Ginsberg,1977; Milbrink,1980; Seather, 1980 and Mastrantuono, 1986). However this concept would not be applicable to highly organically enriched polluted water bodies, where the annelid were completely absent in the sediment. Moreover, while comparing the sites in the same reservoir or the lake, the depth has to be taken in to 
consideration as relative density and distribution of Oligochaetes also depends on depth (Bazanty and Loret, 1982). Anwar and Siddiqui (1988) pointed out that there were two peaks of the abundance of the macro â€-invertebrate fauna; one was the winter peak when the Oligochaetes, Dipteran larvae, Plecoptera and Odonata nymphs and shrimps were abundant, and other was in the monsoon due to the new recruitment of gastropods. The winter and monsoon were the seasons when peak abundance of benthic organisms were recorded (Vasisht and Bhandal,1979). Adarsha et al., (2006) stated that macroinvertebrates like Limnea planarian made their appearance only after the monsoon at all sampling stations. Sharma et al., (2007) observed benthic density high during winter season followed by summer and monsoon at Site Jhar Jhani pond. According to Sahgal (1977) stated seasonal variation in the quantum of the benthic fauna in streams depends upon the interplay of various environmental factors. Hul (1987) recorded 152 taxon in the benthic samples and this high number was undoubtedly determined by low land character of the river. The inflow of domestic sewage constituted a source of readilt accessibly energy and nutrients for the micro-organisms. High seasonal abundance of some of the benthic macro-invertebrtes particularly T. tubifex and $P$. aequiseta in the lake receiving effluents is very interesting and they seemed to be very tolerant of different levels of organic pollution.

\section{Conclusion:}

From the present investigation, it is concluded that littoral benthic macroinvertebrate community is useful in evaluating the localized effects of organic enrichment in the lenthic systems, as profundal zoo-benthos indicate the water quality as a whole (Mastrantuono, 1986).The dominance of molluscan and annelids at Site-I in the present study indicated low organic load and oxygen depleted conditions in this section of the lake. However, further research is needed to evaluate the impact of different types and levels of environmental 
pollutants on macro-zoobenthos to understand their bioindicator value for quick assessment of water.

\section{Reference:}

Adarsh Kumar, Qureshi,T. A. and Parashar Alka (2006). Biodiversity assessment of macro-invertebrates in Ranjit Sagar reservoir, Jammu, J and K, India. J. Aqua. Biol. 21(2):Pp.39-44.

Anwar,S. and Siddiqui,M.S. (1988).On the distribution and dynamics of macroinvertebrate faunqa of the river Kali in North India. J.Envi. Biol.,9(31): Pp.333-341.

Archana Rani,N. (2003).Ecological studies on Saroornagar lake, Hyderabad, with special reference to Zoobenthic communities. Thesis submitted to Osmania University, Hyderabad. Bazzanti,M. and Loret,E.(1982). Macrobenthic community structure in a polluted lake, Lake Nemi (Central Italy).Boll. Zool.,49: Pp.79-91.

Chandrasekhar,S.V.A.(1994). Macro-benthic fauna of the lake Hussainsagar,Hyderabad with reference to Molluscs and chironomid larvae. Rec. Zool. Surv. India.96(1.4): Pp.1-5.

Hul,M.(1987). The effect of domestic sewage on the structure of the Microbenthic Ciliate Communities in the Lyna river.Pol. Arch. Hydrobiol.34(4): Pp.567-578.

Mandal,B.K. and Moitra,S.K. (1975). Studies on the bottom fauna of freshwater fish pond at Burdwan.J. Indian Fish. Soc. India. VII: Pp.43-48.

Mastrantuono,I.(1986). Littoral sand zoo-benthos and their relation to organic pollution in Lake Nemi (Central Italy). Hydrobiological Bulletin.19(2):pp. Pp.171-176.

Michael,R.G.(1968). Studies on bottom fauna in a tropical freshwater fish pond . Hydrobiologia.31: Pp.203-230. 
Millbrink,G. (1978). Indicator communities of Oligochaetes in Scandinavian lakes.Verh. Inter. Verein. Limnol. Pp.2406-2411.

Mylinsky,E.and Ginsburg, W.(1977).Macro-invertebrates as indicators of pollution .J.AWWA.69: Pp.538-542

Reddy, B. K.(1991). Studie on industrial and urban pollution in Kukatpally channel of lake Hussainsagar, Hyderabad.Andhra Pradesh,India. and its impact on algal communities . Ph.D. Thesis submitted .Andhra Pradesh, Vishakhapatnam. Sahagal,K.L.(1977). Reports on the development of Indian fisheries in the streams of India.(Mimco). Sarkar, S.K. (1989). Seasonal abundance of benthic macro-faunain a freshwater pond . Envir, and Ecol.77: Pp.113-116.

Sharma, K.K., Nitasha Sawhney and Serbejit Kaur (2007). Some limnological investigation in Vainganga stream, Katra, Jammu and Kashmir state. J. Aqua.Biol.22 (2): Pp.105-109.

Vasisht, H. S. and Bandal, R. S. (1979).Seasonal variation in benthic fauna in some North Indian lakes and ponds.Indian J. Ecol. 6(2): Pp.33-37.

Vikram Reddy,M.and Malla Rao, B.(1997). Biomonitoring of water quality in urban reservoirs and lakes using benthic macro-invertebrates . National seminar on environmental monitoring and management. S.D.L.C.E.

Kakatiya University, Warangal. 
Table 2: Seasonal variation in macro-zoobenthic organisms of Ashti Lake during 2012-2013.

\begin{tabular}{|c|c|c|c|c|c|c|c|c|c|c|c|c|c|}
\hline \multirow{2}{*}{$\begin{array}{c}\mathbf{S . N} \\
\text {. }\end{array}$} & \multirow{2}{*}{$\begin{array}{c}\text { Macro- } \\
\text { zoobenthic } \\
\text { fauna }\end{array}$} & \multicolumn{3}{|c|}{ Site - I } & \multicolumn{3}{|c|}{ Site-II } & \multicolumn{3}{|c|}{ Site - III } & \multicolumn{3}{|c|}{ Site-IV } \\
\hline & & $\begin{array}{r}\text { Mo } \\
\mathbf{n} \\
\end{array}$ & $\begin{array}{c}\text { Wi } \\
\mathbf{n}\end{array}$ & $\begin{array}{l}\text { Su } \\
\mathbf{m}\end{array}$ & $\begin{array}{r}\text { Mo } \\
\mathbf{n} \\
\end{array}$ & $\begin{array}{c}\mathbf{W} \mathbf{i} \\
\mathbf{n}\end{array}$ & $\begin{array}{l}\text { Su } \\
\mathbf{m} \\
\end{array}$ & $\begin{array}{r}\text { Mo } \\
\mathbf{n} \\
\end{array}$ & $\begin{array}{c}\mathbf{W i} \\
\mathbf{n}\end{array}$ & $\begin{array}{l}\mathbf{S u} \\
\mathbf{m} \\
\end{array}$ & $\begin{array}{r}\text { Mo } \\
\mathbf{n} \\
\end{array}$ & $\begin{array}{c}\mathbf{W i} \\
\mathbf{n}\end{array}$ & $\begin{array}{l}\mathbf{S u} \\
\mathbf{m} \\
\end{array}$ \\
\hline A & NEMATODA & & & & & & & & & & & & \\
\hline 1 & $\begin{array}{l}\text { Diplogaster } \\
\text { factor }\end{array}$ & - & + & + & + & + & - & + & + & - & + & + & + \\
\hline 2 & $\begin{array}{l}\text { Rhabdolimus } \\
\text { minor }\end{array}$ & - & + & - & + & + & - & - & + & - & + & + & - \\
\hline B & ANNELIDA & & & & & & & & & & & & \\
\hline 3 & $\begin{array}{l}\text { Pristina } \\
\text { aequiseta }\end{array}$ & - & + & + & + & + & - & + & + & + & + & + & - \\
\hline 4 & Tubifex tubifex & + & + & + & + & + & + & + & + & - & + & + & + \\
\hline C & ARTHROPODA & & & & & & & & & & & & \\
\hline 5 & $\begin{array}{l}\text { Notonecta } \\
\text { glauca }\end{array}$ & + & - & - & + & + & - & + & - & - & + & + & - \\
\hline 6 & Diptera larva & - & + & + & - & + & + & + & + & - & - & + & + \\
\hline 7 & $\begin{array}{l}\text { Chiromomus } \\
\text { larva }\end{array}$ & + & - & - & + & + & + & + & - & - & + & + & - \\
\hline 8 & Mosquito larva & + & - & - & + & + & - & - & + & + & + & + & - \\
\hline D & MOLLUSCA & & & & & & & & & & & & \\
\hline 9 & $\begin{array}{l}\text { Bellamya } \\
\text { bengalenis }\end{array}$ & + & + & - & - & + & + & + & + & - & + & + & + \\
\hline 10 & $\begin{array}{l}\text { Indoplanorbius } \\
\text { exustus }\end{array}$ & + & + & - & + & + & - & - & + & + & - & + & - \\
\hline 11 & $\begin{array}{l}\text { Thiara } \\
\text { tuberculata }\end{array}$ & + & + & + & + & + & + & + & - & - & + & + & + \\
\hline 12 & Thira scabra & + & - & - & + & + & - & + & - & - & + & + & + \\
\hline 13 & $\begin{array}{l}\text { Lymnaea } \\
\text { accuminata }\end{array}$ & + & - & + & + & + & + & - & + & - & - & + & - \\
\hline 14 & Faunus ater & + & + & - & - & + & - & - & + & + & - & + & + \\
\hline 15 & Pila-globosa & + & + & - & + & - & - & + & + & + & + & - & - \\
\hline 16 & $\begin{array}{l}\text { Ligumia } \\
\text { latissima }\end{array}$ & + & - & + & - & - & - & - & + & + & + & - & + \\
\hline
\end{tabular}

